agriTECH, 40 (4) 2020, 332-339

\title{
Pengaruh Gelombang Mikro terhadap Kualitas Hasil Minyak Atsiri Jahe (Zingiber officinale) dengan Hidrodistilasi
}

\author{
Effect of Microwaves on Yield Quality Ginger Essential Oil (Zingiber officinale) with Hydrodistillation \\ Bambang Dwi Argo*, Febriyanti Ariska Amaliyah \\ Jurusan Keteknikan Pertanian, Fakultas Teknologi Pertanian, Universitas Brawijaya, \\ Jl. Veteran, Lowokwaru, Malang 65145, Indonesia \\ *Penulis korespondensi: Bambang Dwi Argo, E-mail: dwiargo@ub.ac.id
}

Tanggal submisi: 23 November 2018; Tanggal penerimaan: 14 April 2020

\begin{abstract}
ABSTRAK
Komoditi minyak atsiri merupakan salah satu bentuk produk ekspor strategis yang mempunyai nilai ekonomis tinggi, salah satunya adalah minyak atsiri jahe. Metoda ekstraksi minyak atsiri jahe yang optimal masih menjadi topik penelitian dalam upaya untuk meningkatkan kuantitas dan kualitasnya. Tujuan penelitian ini adalah untuk mendapatkan parameter proses pemanasan yang optimal dengan gelombang mikro. Minyak atsiri dengan bahan baku jahe (Zingiber officinale) diperoleh dengan metode hidrodistilasi dan didahului pemanasan dengan gelombang mikro. Gelombang mikro dengan variasi daya 100 dan $180 \mathrm{~W}$ diaplikasikan dengan variasi durasi perlakuan 1, 2, 3, 4, dan 5 menit pada bubuk jahe. Rendemen minyak atsiri, densitas minyak atsiri, indeks bias, bilangan asam, dan kadar zingiberene pada minyak atsiri yang dihasilkan diukur sebagai parameter yang diamati. Hasil penelitian menunjukkan bahwa kombinasi pemanasan dengan gelombang mikro pada daya $100 \mathrm{~W}$ dan durasi 2 menit menghasilkan rendemen sebesar 1,364\%, densitas sebesar 0,889 g/mL indeks bias sebesar 1,49 , bilangan asam sebesar 1,5, dan kadar zingiberene sebesar 24,7\%. Parameter proses pemanasan dengan gelombang mikro sebagai praperlakuan telah berhasil menghasilkan minyak atsiri jahe dengan kuantitas dan kualitas yang lebih baik.
\end{abstract}

Kata kunci: Gelombang mikro; jahe; minyak atsiri; Zingiberene

\begin{abstract}
Essential oil commodity is one form of strategic export product that has high economic value, one of which is ginger essential oil. The optimal method of extraction ginger essential oil is still a research topic in an effort to increase its quantity and quality. The purpose of this research is to obtain the optimal heating process parameters with microwave. Ginger essential oil produced by hydro-distillation and microwave pretreatment with 100 and 180 W of maximum output and 1, 2, 3, 4, and 5 min of pretreatment duration. Parameters of essential oil obtained were evaluated, i.e. yield, density, refractive index; total acid number, and zingiberene content. The results indicated that microwave pretreatment with $100 \mathrm{~W}$ and $2 \mathrm{~min}$ as the best microwave pretreatment combination. The combination produced ginger essential oil with $1.364 \%$ of yield, $0.889 \mathrm{~g} / \mathrm{mL}$ of density, 1.49 of refraction index, 1,5 of total acid number, and $24.7 \%$ of zingiberene content. The parameters of the microwave heating process as pretreatment have succeeded in producing ginger essential oil with better quantity and quality.
\end{abstract}

Keywords: Microwave; ginger; essential oil; Zingiberene 


\section{PENDAHULUAN}

Minyak atsiri atau dikenal juga dengan essential oil, merupakan cairan alami berminyak yang berasal dari bunga, buah, batang atau bagian tanaman lainnya yang diperoleh dengan proses distilasi, fermentasi, atau pengepresan (Hu dkk., 2018). Minyak ini memiliki kandungan zat antibakteri, antijamur, dan antioksidan. Sebagai contoh, minyak atsiri yang didapatkan dari batang kayu manis memiliki zat antioksidan dan aktimikroba karena memiliki kandungan eugenol dan aldehid yang tinggi (Yildrim dkk., 2017). Selain itu, pemanfaatannya berkembang luas tidak hanya untuk bidang kesehatan, tetapi juga untuk pangan. Pires dkk. (2018) mengkaji pemanfaatan minyak atsiri rosmarin dan jahe yang dipadukan dengan chitosanmontmorillonite untuk pelapis daging unggas segar pada proses pengemasannya. Pemanfaatan minyak atsiri lainnya di bidang pangan sebelumnya telah banyak dilakukan, seperti pemanfaatan untuk edible film (Alexandre dkk., 2016; Noshirvani dkk., 2017; Bonilla dkk., 2018), mikroenkapsulasi (Fernandes dkk., 2016), dan edible coating pada daging ayam (Noori dkk., 2018).

Salah satu tanaman yang umum digunakan sebagai bahan minyak atsiri adalah jahe (Zingiber officinale). Jahe merupakan salah satu bahan rempah paling banyak digunakan di dunia. Minyak atsiri jahe dilaporkan memiliki kandungan yang kuat dari antimikroba, antijamur dan antioksidan (Noori dkk., 2018). Kandungan kimia utama dari minyak atsiri jahe adalah a-zingiberene, camphene, ar-curcumene dan $\beta$-sesquiphellandrene (Singh dkk., 2005). Pemanfaatannya di bidang pangan dan kesehatan juga telah banyak diteliti.

Mayoritas minyak atsiri umumnya didapatkan melalui proses distilasi air (hidrodistilasi). Namun demikian, hasil hidrodistilasi biasa umumnya tidak menentu dengan effisiensi rendah (Chen dkk., 2018), baik dari segi kualitas maupun kuantitas minyak atsiri yang dihasilkan. Guna meningkatkan hasil distilasi, banyak metode baru yang dikembangkan, seperti ekstraksi dengan bantuan gelombang mikro, ekstraksi super kritis, dan hidrodistilasi dengan bantuan gelombang mikro (Mesomo dkk., 2016; Chen dkk., 2018; Markovic dkk., 2018). Selain itu, pengembangan juga dilakukan dengan menambahkan proses praperlakuan pada bahan minyak atsiri sebelum proses distilasi dilakukan. Praperlakuan yang diberikan bisa berupa praperlakuan gelombang mikro dan enzim (Chen dkk., 2018), praperlakuan perendaman dan penggilingan (Markovic dkk., 2018), praperlakuan elektrofluida (Wiasiu dkk., 2017), dan praperlakuan ultrasonik (Damyeh dkk., 2016). Praperlakuan gelombang mikro terhadap bubuk jahe dengan ukuran 35 mesh dengan berbagai variasi waktu dan daya merupakan hal yang baru dari peneltian ini, dan untuk pertimbangan kebutuhan energy minimum dipilih praperlakuan dengan daya 100 dan 180W.

Berdasarkan studi literatur, potensi tanaman jahe sebagai sumber minyak atsiri adalah sangat besar di Indonesia. Penelitian ini bertujuan untuk meneliti pengaruh praperlakuan gelombang mikro pada rendemen dan sifat fisik minyak atsiri jahe yang dihasilkan dari hidrodistilasi meliputi juga kuantifikasi kandungan zat aktif zingiberene dari minyak atsiri jahe yang dihasilkan dari kombinasi praperlakuan gelombang mikro terbaik.

\section{METODE PENELITIAN}

\section{Persiapan Bahan}

Rimpang jahe putih dibeli dari pasar lokal di Kota Malang, Jawa Timur, kemudian dibersihkan dari pengotor dengan air mengalir dan ditiriskan. Rimpang jahe bersih kemudian dikupas dan diiris manual dengan ketebalan $\pm 2 \mathrm{~mm}$ dengan pisau. Jahe iris kemudian dikeringkan selama dua hari kemudian dilakukan pengecilan ukuran dengan disc mill. Jahe bubuk kemudian dilakukan penyeragaman ukuran dengan ayakan berukuran 35 mesh untuk selanjutnya dilakukan pemanasan dengan gelombang mikro.

\section{Praperlakuan Gelombang Mikro}

Untuk satu kali proses hidrodistilasi, $100 \mathrm{~g}$ bubuk jahe ditempatkan dalam gelas kimia untuk kemudian diberikan paparan dengan gelombang mikro. Praperlakuan gelombang mikro dilakukan dengan variasi dua faktor perlakuan, yaitu daya keluaran gelombang mikro (100 dan $180 \mathrm{~W}$ ) dan durasi praperlakuan (1, 2, 3 , 4, dan 5 menit). Bubuk jahe yang telah diberi paparan gelombang mikro siap untuk proses hidrodistilasi (Syikri, 2018)

\section{Hidrodistilasi dan Pemurnian Minyak Atsiri Jahe}

Proses hidrodistilasi dilakukan dengan seperangkat alat distilasi berbahan kaca. Jahe bubuk yang sudah dikenakan paparan gelombang mikro dilarutkan ke dalam akuades dengan perbandingan $1: 15 \mathrm{~b} / \mathrm{v}$. Hidrodistilasi dilakukan selama 3 jam yang dimulai dari tetes pertama uap hasil kondensasi. Minyak yang diperoleh selanjutnya dilakukan pemisahan (filtrasi) dari cairan distilat dengan corong pemisah. Minyak yang telah dipisahkan selanjutnya ditambahkan dengan $\mathrm{Na}_{2} \mathrm{SO}_{4}$ anhidrous secukupnya untuk mengikat air yang terkandung dalam minyak (Supardan dkk, 2009). 
Minyak yang diperoleh kemudian dilakukan pengukuran rendemen.

\section{Pengujian Sifat Fisik Minyak Atsiri Jahe dan Pemilihan Praperlakuan Terbaik}

Sifat fisik minyak atsiri jahe yang diukur meliputi berat jenis dengan piknometer, indeks bias dengan refraktometer, dan bilangan asam dengan metoda titrasi KOH (Supriono, 2014). Hasil ketiga parameter tersebut dari semua variasi praperlakuan yang dicobakan kemudian dibandingkan dengan Standar Nasional Indonesia (SNI) No. 06-1312-1998 untuk minyak atsiri jahe.

\section{Kuantifikasi Kandungan Zingiberena}

Kandungan zat aktif zingiberene dari minyak atsiri jahe yang dihasilkan dari kombinasi praperlakuan terbaik diukur dengan gas chromatography-mass spectrometry (GC-MS). Minyak atsiri konsentrasi 1,36\% dalam toluena dianalisis dengan GC-MS di Laboratorium Kimia Organik, Fakultas MIPA Universitas Brawijaya, dengan kondisi berikut: gas pembawa He; kolom Rastex RXi5MS; panjang kolom $30 \mathrm{~m}$; ID 0,25 mm; jenis pengion EI (Electron impact); kecepatan gas $80,0 \mathrm{~mL} / \mathrm{menit}$; kenaikan suhu $10^{\circ} \mathrm{C} /$ menit; suhu awal $60^{\circ} \mathrm{C}$; suhu akhir $290{ }^{\circ} \mathrm{C}$; suhu detektor $250{ }^{\circ} \mathrm{C}$; suhu injector $300{ }^{\circ} \mathrm{C}$; tekanan kolom 10,9 kPa; waktu awal 5 menit; waktu akhir 70 menit.

\section{HASIL DAN PEMBAHASAN}

\section{Rendemen Minyak Atsiri Jahe}

Rendemen hasil minyak atsiri jahe dengan berbagai kombinasi praperlakuan gelombang mikro disajikan pada Gambar 1. Berdasarkan data hasil penelitian dari berbagai perlakuan, rendemen minyak yang diperoleh

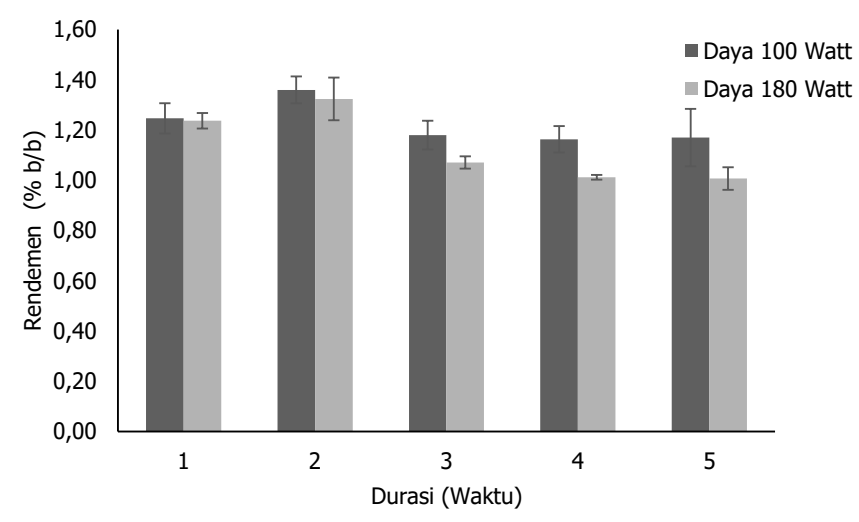

Gambar 1. Grafik nilai rendemen terhadap waktu dengan variasi daya $100 \mathrm{~W}$ dan $180 \mathrm{~W}$ berkisar antara 1,007-1,364\%, sedangkan untuk sampel kontrol sebesar $1,163 \%$.

Gambar 1 di atas menunjukkan bahwa hasil rendemen minyak jahe tertinggi didapatkan pada luaran daya $100 \mathrm{~W}$ dan durasi praperlakuan 2 menit dengan nilai $1,360 \%$, sedangkan rendemen minyak jahe terendah didapatkan pada daya luaran 180 Watt dan durasi praperlakuan 5 menit dengan nilai 1,007\%. Berdasarkan hasil tersebut dapat terlihat adanya kenaikan rendemen yang diperoleh pada perlakuan menggunakan luaran daya 100 Watt dengan durasi praperlakuan 1-3 menit, sedangkan untuk penggunaan daya luaran 180 Watt kenaikan rendemen terjadi pada durasi praperlakuan 1-2 menit. Hal ini dapat dikarenakan penggunaan durasi praperlakuan yang lebih lama pada kedua luaran daya tersebut akan mengakibatkan sampel terdegradasi atau mengalami kerusakan akibat suhu yang terlalu tinggi saat proses praperlakuan berlangsung. Pernyataan tersebut diperkuat oleh hasil penelitian (Argawal,2001) yang menyatakan bahwa zingiberene bersifat thermolabile atau mudah rusak apabila terpapar suhu yang tinggi. Hasil ini sesuai dengan pernyataan Purwanto dkk. (2010) yang menyatakan bahwa luaran daya pada alat pembangkit gelombang mikro serta durasi praperlakuan merupakan dua faktor yang saling mempengaruhi. Kombinasi daya luaran dan durasi waktu praperlakuan perlu ditentukan untuk menghindari terjadinya degradasi termal, serta efisiensi ekstraksi meningkat pada penggunaan daya rendah dengan waktu yang singkat. Hal ini diperkuat oleh pendapat Kurniasari (2008) yang menyatakan bahwa ekstraksi menggunakan gelombang mikro tidak memerlukan suhu yang tinggi. Hal ini dikarenakan pemanasan menggunakan gelombang mikro memberikan banyak keuntungan yaitu pemanasan yang relatif lebih cepat (Handayani dkk., 2014). Pemanasan menggunakan gelombang mikro terjadi melalui proses yang disebut pemanasan dielektrik atau pergerakan dari senyawa dipole yang bermuatan positif dan negatif. Pergerakan dipole listrik tersebut menghasilkan energi panas yang lebih efektif. Pemanasan dengan gelombang mikro mampu mengurangi resiko kerusakan bahan. Dari Gambar 1 dapat disimpulkan bahwa pada penelitian ini rendemen tertinggi diperoleh pada praperlakuan dengan menggunakan daya luaran rendah, yakni $100 \mathrm{~W}$ dan waktu proses selama 2 menit.

\section{Sifat Fisik Minyak Atsiri Jahe}

Sifat fisik minyak atsiri jahe dengan berbagai kombinasi praperlakuan gelombang mikro yang dihasilkan disajikan pada Gambar 2, 3. dan 4. Gambar 2 menyajikan hubungan antara densitas minyak atsiri 
jahe dengan perlakuan luaran daya dan durasi waktu proses. Gambar 3 menggambarkan hubungan antara masa jenis dengan luaran daya dan waktu proses dan Gambar 4 menunjukan hubungan antara bilangan asam dari minyak atsiri jahe dengan perlakuan luaran daya dan waktu proses. Berdasarkan hasil penelitian yang telah dilakukan, nilai berat jenis, indeks bias, dan bilangan asam berturut-turut berkisar pada 0,838-0,893 $\mathrm{g} / \mathrm{mL}, 1,490-1,493$, dan 1,070-2,100.

Pada Gambar 2 dapat dilihat bahwa pada penggunaan daya luaran $100 \mathrm{~W}$ nilai dari densitas minyak jahe mengalami kenaikan pada durasi praperlakuan 1-2 menit, dimana pada praperlakuan dua menit nilai berat jenis yang dihasilkan merupakan nilai tertinggi yang memenuhi Standar Nasional Indonesia sebagaimana disajikan pada Tabel 2. Adanya kenaikan nilai berat jenis mengindikasikan bahwa penggunaan gelombang mikro sebagai praperlakuan mampu meningkatkan kandungan senyawa yang diperoleh dari proses pemecahan sel. Hal ini sesuai dengan pernyataan Nugraheni dkk. (2016) yang menyatakan bahwa berat jenis suatu zat dipengaruhi oleh jumlah dan jenis senyawa yang terdapat didalamnya, semakin tinggi komponen yang memiliki rantai panjang atau memiliki gugus oksigen maka kerapatan minyak akan bertambah. Pada durasi praperlakuan 3-5 menit, berat jenis yang diperoleh mengalami penurunan. Hal ini diakibatkan pada penggunaan gelombang mikro dengan durasi yang lama memungkinkan adanya degradasi pada senyawa akibat proses termal. Sehingga kerapatan dan jumlah senyawa berkurang yang menyebabkan berat jenis yang diperoleh juga mengalami penurunan. Pada penggunaan daya luaran $180 \mathrm{~W}$, berat jenis yang dihasilkan lebih rendah dibandingkan pada penggunaan daya luaran $100 \mathrm{~W}$. Hal ini dapat disebabkan pada penggunaan daya luaran yang lebih tinggi, memungkinkan senyawa yang dihasilkan mengalami kerusakan akibat proses termal. Kondisi ini didukung oleh pernyataan Purwanto dkk. (2010) yang menyatakan bahwa efisiensi ekstraksi meningkat pada daya luaran 30-150 W dengan durasi praperlakuan yang singkat, sehingga meningkatkan penguapan senyawa volatile pada jahe dan berakibat pada penurunan nilai berat jenis yang dihasilkan. Pada durasi praperlakuan 4-5 menit, terjadi kenaikan nilai densitas minyak atsiri yang dihasilkan. Hal ini diduga karena adanya senyawa lain hasil pemecahan sel saat menggunakan gelombang mikro yang ikut tersuling. Pemecahan sel oleh gelombang mikro tidak hanya memecahkan jaringan minyak atsiri saja. Hal ini didukung oleh hasil penelitian Sukardi dkk (2016) yang menyatakan bahwa semakin besar terbentuknya pori saat proses praperlakuan, maka pelarut mampu menjangkau bagian jaringan lebih dalam. Karenanya saat proses distilasi, komponen yang

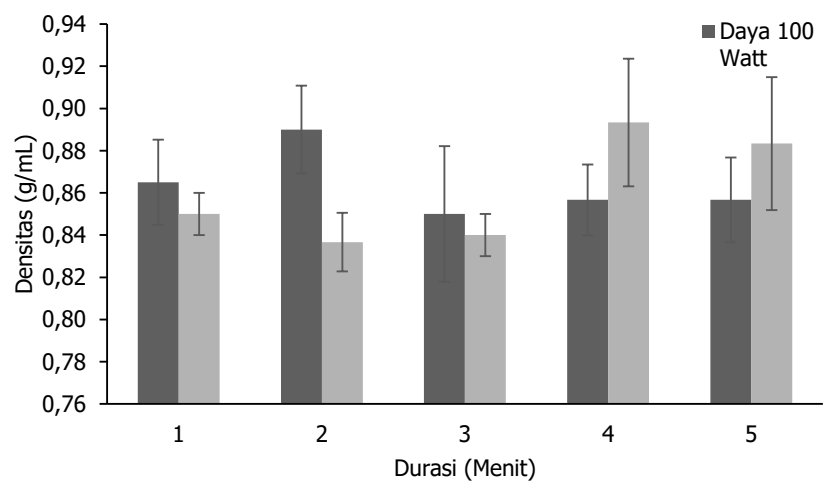

Gambar 3. Grafik pengaruh waktu dan daya praperlakuan terhadap nilai indeks bias minyak jahe

tersuling lebih kompleks. Terbentuknya pori yang lebih besar selaras dengan penggunaan daya luaran yang lebih tinggi dengan durasi praperlakuan yang lama. Kondisi tersebut mampu meningkatkan panas yang terbentuk dari gesekan molekul dalam bahan sehingga sel pecah, dan sebagai akibatnya terbentuk pori yang semakin irreversible (Gotama dkk., 2017). Peningkatan laju ekstraksi pada minyak jahe dapat berakibat pada penguapan senyawa volatil pada minyak jahe.

Data pada Gambar 3 menunjukkan nilai indeks bias pada seluruh sampel dengan berbagai perlakuan telah sesuai dengan Standar Nasional Indonesia untuk minyak atsiri jahe, kecuali pada praperlakuan daya luaran $100 \mathrm{~W}$ dengan durasi 3 menit yang lebih tinggi dari standar yang ditentukan, yakni 1,493, sehingga dapat disimpulkan bahwa kombinasi tersebut merupakan praperlakuan terbaik pada penelitian ini. Menurut Qorriaina dkk. (2015), penentuan indeks bias dilakukan untuk mengetahui kandungan air dalam minyak. Sehingga jika kandungan air dalam minyak semakin banyak, maka nilai indeks bias minyak semakin kecil.

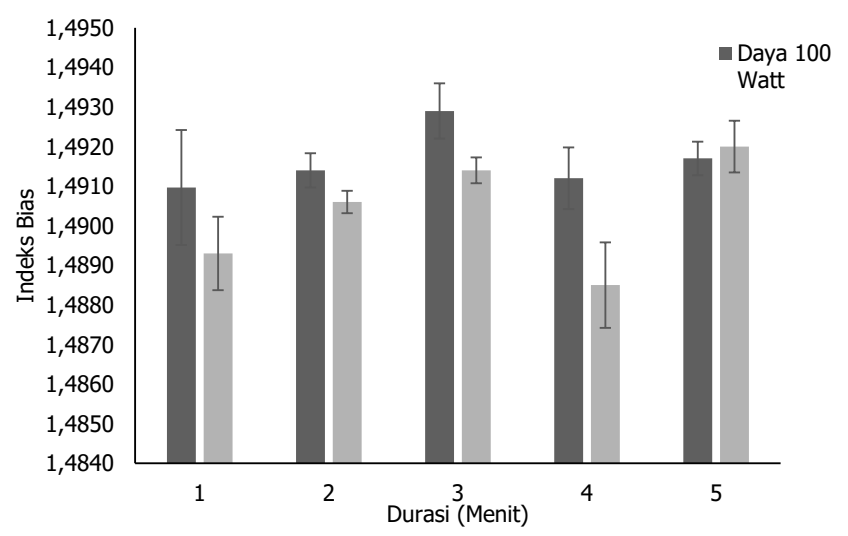

Gambar 4. Grafik pengaruh waktu dan daya praperlakuan terhadap nilai bilangan asam minyak jahe 
Bilangan asam minyak atsiri menunjukan jumlah asam bebas yang terkandung dalam minyak. Jumlah asam bebas yang terkandung dalam minyak atsiri pada umumnya terbilang rendah yang dinyatakan dalam bilangan asam. Penentuan bilangan asam diartikan sebagai jumlah miligram $\mathrm{KOH}$ yang dibutuhkan untuk menetralkan asam bebas dalam $1 \mathrm{~g}$ minyak Hildani (2015). Bilangan asam yang terlalu tinggi pada minyak atsiri mampu mempengaruhi kualitas minyak, diantaranya mengubah aroma khas minyak itu sendiri (Amrullah dkk., 2017). Senyawa asam yang terdapat dalam minyak atsiri merupakan hasil reaksi oksidasi antara minyak dengan udara yang dikatalisasi dengan bantuan cahaya (Amrullah dkk., 2017). Jika dibandingkan dengan standar mutu minyak atsiri jahe berdasarkan Standar Nasional Indonesia, terdapat sampel dengan nilai bilangan asam yang belum memenuhi persyaratan, yaitu maksimal 2. Berdasarkan data pada Gambar 4 nilai bilangan asam terendah diperoleh pada sampel dengan perlakuan daya luaran $180 \mathrm{~W}$ dan durasi praperlakuan 2 menit. Sampel dengan nilai bilangan asam tertinggi diperoleh pada sampel dengan praperlakuan daya luaran $180 \mathrm{~W}$ dan durasi 1 menit dan kontrol.

\section{Kombinasi Praperlakuan Terbaik}

Penentuan minyak atsiri jahe hasil praperlakuan gelombang mikro terbaik didasarkan pada hasil pengamatan sifat fisik (Gambar 1, 2, 3, dan 4) yang dikomparasikan dengan Standar Nasional Indonesia untuk minyak atsiri jahe. Menurut Qorriaina dkk. (2015) parameter-parameter yang dipertimbangkan untuk menentukan kualitas minyak atsiri jahe berturut-turut adalah berat jenis, indeks bias, bilangan asam, dan rendemen. Dengan konsideran-konsideran tersebut, kombinasi praperlakuan gelombang mikro terbaik disajikan pada Tabel 1.

Tabel 1 menunjukan bahwa minyak atsiri jahe yang diperoleh dari hasil praperlakuan dengan gelombang mikro memiliki kualitas yang lebih baik jika dibandingkan dengan sampel kontrol pada keseluruhan parameter penelitian. Berat jenis dan indeks bias minyak hasil praperlakuan memiliki nilai yang lebih baik jika dibandingkan sampel kontrol, dimana semakin tinggi nilai berat jenis dan indeks bias maka kualitas minyak semakin baik. Selain itu, nilai berat jenis dan indeks bias hasil praperlakuan telah sesuai dengan syarat mutu Standar Nasional Indonesia.

\section{Kandungan Zat Aktif Zingiberene}

Hasil analisis GC-MS pada minyak atsiri jahe dengan praperlakuan terbaik dan kontrol mengindikasikan bahwa jumlah senyawa yang teridentifikasi sebanyak 20 puncak (senyawa) (Gambar 5) pada perlakuan kontrol maupun praperlakuan. Pada sampel kontrol maupun praperlakuan diperoleh 15 senyawa yang termasuk kedalam komponen minyak jahe, dimana 3 senyawa di dalamnya teridentifikasi sebanyak 2 kali pada puncak kromatogram. Pengelompokan senyawa ini didasarkan pada nilai surface ionization (SI). Uji zat aktif pada minyak atsiri jahe bertujuan untuk melihat perbedaan kadar zingiberena minyak atsiri jahe pada sampel kontrol dan sampel hasil praperlakuan. Perbandingan kadar

Tabel 2. Kadar zat aktif zingiberene minyak atsiri jahe

\begin{tabular}{lc}
\hline Sumber & Kadar Zingiberena (\%) \\
\hline $\begin{array}{l}\text { Kontrol } \\
\text { Praperlakuan (100 W, } 2\end{array}$ & $24,8 \pm 0,1$ \\
menit) & $24,7 \pm 0,1$ \\
\hline
\end{tabular}

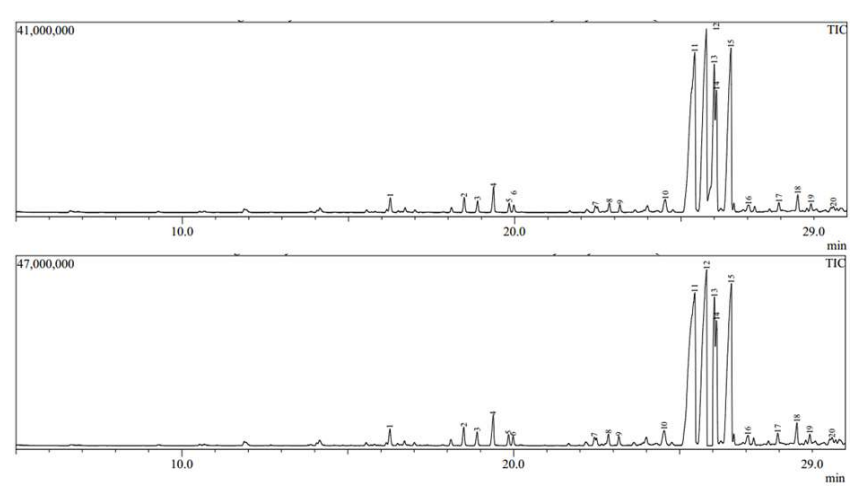

Gambar 5. Kromatogram minyak atsiri jahe (Kontrol: atas; Praperlakuan: bawah)

Tabel 1. Sifat fisik minyak atsiri dengan kombinasi praperlakuan terbaik dan komparasinya dengan SNI

\begin{tabular}{lccc}
\hline \multicolumn{1}{c}{ Parameter } & $\begin{array}{c}\text { Praperlakuan } \\
(100 \text { Watt, } 2 \text { min })\end{array}$ & Kontrol & SNI No. 06-1312-1998 \\
\hline Berat jenis & $0,89 \pm 0,02$ & $0,86 \pm 0,04$ & $0,8720-0,8890$ \\
Indeks bias & $1,49 \pm 0,04$ & $1,49 \pm 0,06$ & $1,4853-1,4920$ \\
Bilangan asam & $1,50 \pm 0,06$ & $2,20 \pm 0,07$ & Maks. 2 \\
\hline
\end{tabular}


Tabel 3. Kandungan senyawa hasil analisis dengan GC-MS

\begin{tabular}{|c|c|c|c|}
\hline $\begin{array}{l}\text { No. puncak } \\
\text { (pick) }\end{array}$ & Nama & $\begin{array}{c}\text { Tinggi }(\%) \\
\text { praperlakuan }\end{array}$ & $\begin{array}{l}\text { Tinggi }(\%) \\
\text { kontrol }\end{array}$ \\
\hline 1 & Borneol $\left(\mathrm{C}_{10} \mathrm{H}_{18} \mathrm{O}\right)$ & 1,7 & 1,54 \\
\hline 2 & Z-Citral ((2Z)-3,7-dimethylocta-2,6-dienal) & 1,88 & 1,56 \\
\hline 3 & Trans-Geraniol $\left(\mathrm{C}_{10} \mathrm{H}_{18} \mathrm{O}\right)$ & 1,42 & 1,21 \\
\hline 4 & E-Citral (trans-3,7-dimethylocta-2,6-dienal) & 3,10 & 2,64 \\
\hline 5 & Acetic Acid $\left(\mathrm{CH}_{3} \mathrm{COOH}\right)$ & 1,12 & 0,97 \\
\hline 6 & Alpha-Fenchyl Acetate $\left(\mathrm{C}_{12} \mathrm{H}_{20} \mathrm{O}_{2}\right)$ & 0,95 & 0,75 \\
\hline 7 & Alpha Cubebene $\left(\mathrm{C}_{15} \mathrm{H}_{24}\right)$ & 0,85 & 0,69 \\
\hline 8 & Beta elemene $\left(\mathrm{C}_{15} \mathrm{H}_{24}\right)$ & 1,08 & 0,89 \\
\hline 9 & Zingiberene $\left(\mathrm{C}_{15} \mathrm{H}_{24}\right)$ & 0,92 & 0,78 \\
\hline 10 & $\begin{array}{l}\text { Beta sesquiphellandrene (3-(6-methylhept-5-en-2-yl)-6- } \\
\text { methylidenecyclohexene) }\end{array}$ & 1,49 & 1,32 \\
\hline 11 & Benzene $\left(\mathrm{C}_{6} \mathrm{H}_{6}\right)$ & 15,96 & 17,12 \\
\hline 12 & Zingiberene $\left(\mathrm{C}_{15} \mathrm{H}_{24}\right)$ & 18,43 & 19,60 \\
\hline 13 & Farnesene $((\mathrm{E}, \mathrm{E})$-alpha-farnesene $)$ & 15,48 & 15,82 \\
\hline 14 & Beta Bisabolene $\left(\mathrm{C}_{15} \mathrm{H}_{24}\right)$ & 12,96 & 13,02 \\
\hline 15 & $\begin{array}{l}\text { Beta sesquiphellandrene -(6-methylhept-5-en-2-yl)-6- } \\
\text { methylidenecyclohexene) }\end{array}$ & 16,82 & 17,55 \\
\hline 16 & Sesquisabinene hydrate $\left(\mathrm{C}_{15} \mathrm{H}_{26} \mathrm{O}\right)$ & 0,93 & 0,68 \\
\hline 17 & Sesquisabinene hydrate $\left(\mathrm{C}_{15} \mathrm{H}_{26} \mathrm{O}\right)$ & 1,12 & 0,89 \\
\hline 18 & $\begin{array}{l}\text { Zingiberenol (alpha,alpha,4-Trimethyl-1-Cyclohexene-1- } \\
\text { methanol) }\end{array}$ & 2,23 & 1,75 \\
\hline 19 & $\begin{array}{l}\text { Zingiberenol (alpha,alpha,4-Trimethyl-1-Cyclohexene-1- } \\
\text { methanol) }\end{array}$ & 0,97 & 0,77 \\
\hline 20 & VERIDIFLOROL $\left(\mathrm{C}_{15} \mathrm{H}_{26} \mathrm{O}\right)$ & 0,59 & 0,44 \\
\hline
\end{tabular}

zingiberena hasil analisa GC-MS dapat dilihat pada Tabel 2. Jika dibandingkan dengan penelitian sebelumnya oleh Purwanto dkk. (2010) yang menghasilkan kadar zingiberena $19,79 \%$, kadar zingiberena pada minyak atsiri jahe hasil penelitian ini lebih tinggi.

Kandungan senyawa hasil analisis dengan GC-MS ditampilkan pada Tabel 3.

\section{KESIMPULAN}

Praperlakuan gelombang mikro dengan daya luaran yang rendah dan durasi aplikasi yang relative pendek cenderung lebih menghasilkan hasil minyak atsiri jahe dengan masa jenis, indeks bias dan bilangan asam memenuhi standar nasional industri. Aplikasi praperlakuan gelombang mikro dengan daya luaran yang lebih tinggi dengan durasi aplikasi yang lebih lama cenderung menghasilkan efek termal yang ditandai dengan kenaikan bilangan asam dan menurunnya masa jenisnya dari minyak atsiri jahe yang dihasilkan. Hasil penelitian menunjukkan bahwa kombinasi praperlakuan gelombang mikro dengan daya $100 \mathrm{~W}$ dengan durasi 2 menit adalah perlakuan terbaik dengan menghasilkan rendemen, densitas, indeks bias, bilangan asam dan kadar zingiberena berturut-turut sebesar 1,364\%, 0,889 $\mathrm{g} / \mathrm{mL}, 1,49,1,5$, dan $24,7 \%$.

\section{UCAPAN TERIMA KASIH}

Ucapan terima kasih Penulis sampaikan pada Program OPF Fakultas Teknologi Pertanian, Universitas Brawijaya TA 2018 yang telah mendanai penelitian minyak atsiri jahe ini. 


\section{KONFLIK KEPENTINGAN}

Penulis menyatakan bahwa tidak ada konflik kepentingan pada publikasi artikell ini.

\section{DAFTAR PUSTAKA}

Agarwal,N. (2001),Insect growth inhibition, antifeedant and antifungal activity of compounds isolated/derived from Zingiber officinaleRoscoe (ginger) rhizomes. NCBI.

Amrullah, R., Nurjanah, S., Widyasanti, A., Muhaemin, M. (2017). Kajian pengaruh rasio refluks terhadap karakteristik minyak nilam hasil distilasi fraksinasi. Jurnal Teknotan, 11(2).

Alexandre, E. M. C., Lourenco, R. V., Bittante, A. M. Q., Moraes, I. C. F., Sobral, P. J. A. (2016). Gelatin-based films reinforced with montmorillonite and activated with nanoemulsion of ginger essential oil for food packaging applications. Food Packaging and Shelf Life, 10. https:// doi.org/10.1016/j.fpsl.2016.10.004.

Bonilla, J., Poloni, T., Lourenco, R. V., Sobral, P. J. A. (2018). Antioxidant potential of eugenol and ginger essential oils with gelatin/chitosan films. Food Bioscience, 23. https:// doi.org/10.1016/j.fbio.2018.03.007.

Chen, F., Jia, J., Zhang, Q., Yang, Lei, Gu, H. (2018). Isolation of essential oil from the leaves of Polygonum viscosum Buch-ham. using microwave-assisted enzyme pretreatment followed by microwave hydrodistillation concatenated with liquid-liquid extraction. Industrial Crops \& Products, 112. https://doi.org/10.1016/j. indcrop.2017.12.024.

Chen, F., Xu, M., Yang, X, Liu, J., Xiao, Y., Yang, L. (2018). An improved approach for the isolation of essential oil from the leaves of Cinnamomum longepaniculatum using microwave-assisted hydrodistillation concatenated double-column liquid-liquid extraction. Separation and Purification Technology, 195. https://doi.org/10.1016/j. seppur.2017.12.013.

Damyeh, M. S., Niakousari, M., Saharkiz, M. J., (2016). Ultrasound pretreatment impact on Prangos ferulacea Lindl. and Satureja macrosiphonia Bornm. Essential oil extraction and comparing their physicochemical and biological properties. Industrial Crops \& Products, 87. https://doi.org/10.1016/j.indcrop.2016.04.025.

Fernandes, R., V. B., Botrel, D. A., Silva, E. K., Borges, S. V., Oliveira, C. R., Yoshida, M. I., Feitosa, J. P. A., Paula, R. C. M. (2016). Cashew gum and inulin: New alternative for ginger essential oil microencapsulation. Carbohydrate Polymers, 153. https://doi.org/10.1016/j. carbpol.2016.07.096.

Gotama, B., Rahman, D. F., Aris, F. A. (2017). Intensifikasi proses penyulingan minyak atsiri dari daun jeruk purut dengan metode ultrasound following microwave assisted extraction (US-MAE). Indonesian Journal of Essential Oil, 2(1).

Handayani,D., Dinoyo I., Mohamad E.Y. (2014). Ekstraksi Minyak Atsiri dengan Gelombang Mikro untuk Produksi Minyak Jahe (Ginger Oil) berkadar Zingiberen Tinggi. Prosiding PNES II 2014.

Hildani, A. (2015). Penentuan bilangan asam dan bobot jenis serta kelarutan dalam etanol dari minyak nilam (Pogostemon cablin B.). Skripsi. USU. Medan.

Hu, J., Zhang, Y., Xiao, Z., Wang, X. (2018). Preparation and properties of cinnamon-thyme-ginger composite essential oil nanocapsules. Industrial Crops \& Products, 122. https://doi.org/10.1016/j.indcrop.2018.05.058.

Kurniasari, L., Hartati, I., Ratnani, R. D. (2008). Kajian ekstraksi minyak jahe menggunakan microwave assisted extraction (MAE). Momentum 4(2).

Markovic, M. S., Radosavljevic, D. B., Pavicevic, V. P., Ristic, M. S., Milojevic, S. Z., Boskovic-Vragolovic, N. M., Veljkovic, V. B. (2018). Influence of common juniper berries pretreatment on the essential oil yield, chemical composition and extraction kinetics of classical and microwaveassisted hydrodistillation. Industrial Crops \& Products, 122. https://doi.org/10.1016/j. indcrop.2018.06.018.

Mesomo, M. C., Corazza, M. L., Ndiaye, P. M., Santa, O. R. D., Cardozo, L., Scheer, A. P. (2013). Supercritical $\mathrm{CO}_{2}$ extracts and essential oil of ginger (Zingiber officinale R.): Chemical composition and antibacterial activity. The Journal of Supercritical Fluids, 80. https://doi. org/10.1016/j.supflu.2013.03.031.

Noshirvani, N., Ghanbarzadeh, B., Gardat, C., Rezaei, M. R., Hashemi, M., Coz C. L., Coma, V. (2017). Cinnamon and ginger essential oils to improve antifungal, physical and mechanical properties of chitosan-carboxymethyl cellulose films. Food Hydrocoloids, 70. https://doi. org/10.1016/j.foodhyd.2017.03.015.

Noori, S., Zeynali, F., Almasi, H. (2018). Antimicrobial and antioxidant efficiency of nanoemulsion-based edible coating containing ginger (Zingiber officinale) essential oil and its effect on safety and quality attributes of chicken breast fillets. Food Control, 84. https://doi. org/10.1016/j.foodcont.2017.08.015.

Nugraheni, K. S., Khasanah, L. U., Utami, R., Baskara, K. A. (2016). Pengaruh perlakuan pendahuluan dan variasi metode destilasi terhadap karakteristik mutu minyak atsiri daun kayu manis (C. Burmanii). Jurnal Teknologi Hasil Pertanian, 9(2).

Pires, J. R. A., de Souza, V. G. L., Fernando, A. L. (2018). Chitosan/ montmorillonite bionanocomposites incorporated with rosemary and ginger essential oil as packaging for fresh poultry meat. Food Packaging and Shelf Life, 17. https:// doi.org/10.1016/j.fpsl.2018.06.011. 
Purwanto, H., Hartati, I., Kurniasari, L. (2010). Pengembangan microwave assisted extractor (MAE) pada produksi minyak jahe dengan kadar zingiberene tinggi. Momentum, 6(2).

Qorriaina, R., Hawa, L. C., Yulianingsih, R. (2015). Aplikasi praperlakuan microwave assisted extraction (MAE) pada ekstrak daun kemangi (Ocimum sanctum) menggunakan rotary evaporator (Studi pada variasi suhu dan waktu ekstraksi). Skripsi. UB. Malang.

Setyaningsih, W., Saputro, I. E., Palma, M., \& Barroso, C. G. (2016). Pressurized liquid extraction of phenolic compounds from rice (Oryza sativa) grains. Food Chemistry, 192. http://doi.org/10.1016/j. foodchem.2015.06.102.

Singh, G., Maurya, S., Catalan, C., de Lampasona, M. P. (2005). Studies on essential oils, Part 42: Chemical, antifungal, antioxidant and sprout suppressant studies on ginger essential oil and its oleoresin. Flavour and Fragrance Journal, 20. https://doi.org/10.1002/ffj.1373.

Sukardi., Nizar, Mahendra, N., Mulyadi, A.F., Sucipto. (2016). Efek Pulsed Electric Field (PEF) pada rendemen dan kualitas minyak bunga melati (Jasminum sambac) (Kajian rasio bahan dan pelarut). Disertasi Doktor. UB. Malang.
Supardan, D.M., Ruslan., Satriana., Normalina Arpi. (2009). Hidrodistilasi Minyak Jahe (Zingiber officinale Rosc.) Menggunakan Gelombang Ultrasonik. Jurnal Reaktor, Vol. 12 No. 4, Desember 2009, Hal. 239-244

Supriono dan Theresia Adi S. 2014. Kualitas Minyak Atsiri Nilam Dari Metode Pengecilan Ukuran Pada Penyulingan Tanaman Nilam (Pogostemom Cablin Benth). Prosiding Seminar Nasional Kimia, Politeknik Pertanian Negeri Samarinda, Samarinda, 1-6.

Sykri Syahra Pahalati. (2018). Pengaruh Pretreatment Microwave Pada Hidrodistilasi Jahe (Zingiber Officinale) Terhadap Rendemen Dan Kadar Zingiberine Minyak Jahe ( Daya Dan Waktu Pretreatment). Skripsi. UB. Malang

Yildirim, S. T., Oztop, M. H., Soyer, Y. (2017). Cinnamon oil nanoemulsions by spontaneous emulsification: formulation, characterization and antimicrobial activity. LWT-Food Science Technology, 84. https://doi. org/10.1016/j.lwt.2017.05.041.

Wu, F., Jin, Y., Xu, X., Yang, N. (2017). Electrofluidic pretreatment for enhancing essential oil extraction from citrus fruit peel waste. Journal of Cleaner Production, 159. https://doi.org/10.1016/j.jclepro.2017.05.010. 